\title{
CORRUPTION, ANTI-CORRUPTION AND DEMOCRACY IN THE WESTERN BALKANS ${ }^{1}$
}

\author{
Dimitri A. Sotiropoulos \\ University of Athens \\ Department of Political Science and Public Administration
}

\begin{abstract}
SUMMARY
The article discusses corruption, anticorruption and democracy in the Western Balkans, with an emphasis on FYR Macedonia, Montenegro and (less so) Serbia. The article does not advance a claim that its conclusions are valid for all West Balkan democracies. The main question is the following: what the political functions of corruption are (beyond its economic functions) and how corruption serves in reproducing the same elites in power. The research presented in the article shows that high-level or grand political corruption in FYR Macedonia, Montenegro and Serbia, is something larger than a side-benefit of exercising government authority. Such corruption is one of the several means which an elite purposefully uses to stay in power, that was originally attained by winning democratic elections. Furthermore, anticorruption mechanisms are often used with a sole purpose to discredit political opponents, especially those in the opposition. Democracy in the Western Balkans is, thus, distorted in obvious, but also in less obvious ways.
\end{abstract}

KEYwORDS: Western Balkans, corruption, anti-corruption, FYR Macedonia, Montenegro, Serbia

1 Research reported in this article was funded by "Anticorrp", a project included in the European Commission's Seventh Framework Programme (2012-2017) and by the Department of Political Science and Public Administration of the National and Kapodistrian University of Athens, Greece. The article was also prepared for publication In ed. Simendić, Marko. 2017. Demokratski otpori normalizaciji autoritarizma u Evropi/Democratic Ressistance to Authoritarian Trends in Europe Today: Zbornik radova sa redovne međunarodne konferencije Udruženja za političke nauke Srbije/Proceedings of the 2017 Serbian Political Science Association Annual Conference. Beograd: Udruženje za političke nauke Srbije. 
POLITIČKE PERSPEKTIVE

ČLANCI I STUDIJE

\section{INTRODUCTION}

In November 2017 the announcement of European Commission President Jean-Claude Juncker that he expects Serbia and Montenegro to join the European Union (EU) before 2025 revived interest in the Western Balkans. The region's democracies, including Serbia and Montenegro, have been struggling to overcome legacies of the past, including corruption, and there are hopes that the incentive to join the EU will stimulate improvements in anti-corruption.

It is arguable that corruption is not only a misuse of public office for private gain (according to the World Bank's widely used definition) but is also the misuse of public office so as to consolidate one's political power via private benefit. In other words, a corrupt government-business nexus may serve two functions: first it may facilitate the personal enrichment of involved politicians and businessmen, which is typical of corruption cases, regardless of whether the political regime in question is democratic or not; and second it may also foster and prolong the involved politicians' grip on power by securing support for the involved politicians by social interests which benefit from corrupt practices and can help politicians win elections. Social interests supportive of such arrangements may be business and mass media elites as well as civil servants and parts of the public bureaucracy sharing the spoils flowing from corruption. In democratic regimes, the corruption-incited support is vital for the return of a governing party or coalition of parties to power through elections.

Moreover, in democracies anti-corruption, namely the passage of legislation and mobilization of designated state agencies to fight corruption, while ostensibly serving its main purpose to limit corruption, can also function as a tool of political party competition and more specifically as a means of political domination of the governing elites over political parties of the opposition and civic associations challenging the elected government.

In this article, I am going to discuss corruption, anticorruption and democracy in the Western Balkans, with an emphasis on FYR Macedonia, Montenegro and (less so) Serbia. The article does not advance a claim that its conclusions are valid for all West Balkan democracies, as they are quite different. The main question is the following: what the political functions of corruption are (beyond its economic functions) and how corruption serves in reproducing the same elites in power. The research is based on a variety of data, including international statistics, official reports of international organizations, press articles, and the relevant academic literature. 


\section{WHAT IS NOTEWORTHY ABOUT CORRUPTION IN WESTERN BALKANS}

In Western Balkans there have been infrequent successes of the fight against corruption. Examples are the conviction to prison of the Montenegrin former president of the State Union of Serbia and Montenegro, Svetozar Marović, in May 2016 (Tomovic 2016) and the conviction of one of Serbia's largest businessmen of Serbia, Miroslav Miskovic, in June 2016 (Pantovic 2016). One can add the criminal investigations against Nikola Gruevski, the former Prime Minister (PM) of FYR Macedonia and leader of VMRODPMNE, in the spring of 2017. Investigations concerned the revelation of twenty thousand $(20,000)$ wire-taped confidential telephone conversations, including conversations of government ministers and officials of FYR Macedonia, in the spring of 2015 (Zaev 2015). Tapes were leaked through unknown channels to the opposition, the Social Democratic Party (the SDSM). Except for evidence on rigging elections and abusing state resources, the tapes revealed plans of cabinet members, including endeavors of the former PM Nikola Gruevski, to engage in murky business deals, arbitrarily arrange public procurement and illegally seize landed property (Bieber 2015).

While not negligible, these are relatively small accomplishments, as West Balkan democracies today are widely considered to be very corrupt. Comparatively speaking, they are perceived as more corrupt than other European democracies, including East European ones. This is a pattern which emerges from various qualitative and quantitative assessments.

There are several qualitative aspects which account for setting the democracies of Western Balkans apart from other European democracies also thought to be quite corrupt. To start with, in 2013 the Council of Europe's Group of Countries against Corruption (GRECO), after acknowledging that progress in the fight against corruption had been made in FYR Macedonia, reported that "much remains to be done [for]... a better implementation of the legal framework and to improve the public image of Members of Parliament (MPs), judges and prosecutors" (GRECO 2013, 5). Regarding Serbia in 2015 the same international organization observed that "Serbia has come a long way in creating a regulatory and institutional framework for fighting corruption, but much remains to be done to have the system work properly and to close the noticeable gap between the law and practice" (GRECO 2015a, 3). As for Montenegro, in the same year the Council of Europe concluded that "corruption continues to be an important concern in Montenegro, resulting in disquieting figures as to citizens' trust in some of their key institutions, notably the political class and the judiciary" (GRECO 2015b, 3). 
Moreover, the otherwise diplomatic language of the European Commission's annual Progress Reports changed when discussing the fight against corruption in 2015 in FYR Macedonia: "The country has some level of preparation in the fight against corruption. No progress has been achieved in the past year on the outstanding issues identified. Corruption remains widespread" (emphasis in the original; European Commission 2015a, 15). "Montenegro has achieved some level of preparation in the fight against corruption. Corruption remains prevalent in many areas and continues to be a serious problem" (European Commission 2015b, 14). "Serbia has some level of preparation in the fight against corruption. Some progress has been achieved in the past year...However, corruption remains widespread." (emphasis in the original; European Commission 2015c, 13).

Further on, in Western Balkans corruption is often discussed in conjunction with organized crime. However, corruption and organized crime are not the same, as the latter involves the use of violence to commit smuggling of illegal goods, human trafficking, and organ trade, among other criminal law violations. Even though international observers, when discussing corruption in Western Balkans may tend to discuss crime and corruption together (Van Ham 2014). Organized crime is not a distinctive characteristic of West Balkan states, as it can also be found in a few other EU Member - States, e.g., Bulgaria and Italy. The specificity of the Western Balkans is the following: while corruption is observed in other European countries, in Western Balkan countries it has overflowed into practices of organized crime, while the fight against corruption has started only recently and has not borne but few fruits (European Parliament 2015).

In addition, there is a close linkage between political corruption and highly problematic market economies. Not all corruption involves politicians. It may involve illegal exchanges in the private sector, such as the paying of bribes to obtain insider information about a business company. Corruption in the private sector, which is not directly related to the conduct of national politics, may be indicative of a larger issue of unregulated or "wild" capitalism. Capitalism functioning under a few or no rules may be a distinct variety of capitalism in the Western Balkans (Bartlett 2007). The development of this type of capitalism is related to the ubiquity and political uses to which corruption and anti-corruption are put in the countries under study.

To conclude this section, one can claim that Western Balkans stand out for an additional, less expected, specific reason: in Western Balkans, opponents of governing elites have found themselves implicated in cases of corruption, as anti-corruption agencies turned against them rather than against members of governing elites. Anti-corruption, managed through designated state agencies, has been used by governments to inflict polit- 
ical wounds on the opposition. Such phenomena result from a purposeful strategy of governing elites in the three mentioned countries to employ corruption and anti-corruption, not only to enrich themselves but also, if not primarily, to prolong their stay in power.

\section{The estimated extent of corruption}

The claim about the quite large extent of corruption in Western Balkans is corroborated by World Bank's Worldwide Governance indicators' database. One of the database's indicators is "control of corruption", which is understood by the Bank to "capture perceptions of the extent to which public power is exercised for private gain, including both petty and grand forms of corruption, as well as 'capture' of the state by elites and private interests” (World Bank 2015). Following the World Bank's methodology, Table 1 shows the relative percentile rank of the countries included in the table, with higher values corresponding to better performance in controlling corruption. Except for Bosnia-Herzegovina and Bulgaria, all other countries seemed to be able to control corruption better in 2015 than in 2003. Yet, they remained below the percentile rank on the average attained by Central East European countries.

Table 1. Control of Corruption in the Western Balkans in the Comparative Perspective of Eastern Europe, According to World Bank's Governance Indicators

\begin{tabular}{|l|c|c|}
\hline & $\mathbf{2 0 0 3}$ & $\mathbf{2 0 1 5}$ \\
\hline Albania & 26 & 40 \\
\hline Bosnia-Herzegovina & 47 & 45 \\
\hline Croatia & 60 & 63 \\
\hline FYR Macedonia & 31 & 54 \\
\hline Kosovo & 23 & 37 \\
\hline Montenegro & 40 & 56 \\
\hline Serbia & 41 & 51 \\
\hline Bulgaria & 55 & 49 \\
\hline Romania & 47 & 58 \\
\hline Centr East Europe average & 71.6 & 67.4 \\
\hline
\end{tabular}

Source: http://info.worldbank.org/governance/wgi/index.aspx\#home, last accessed on 04.10.2016. The Central Eastern European average is the average of scores of the Czech Republic, Hungary, Poland, Slovakia and Slovenia. The closer the score to 0, the less capable of controlling corruption a country is perceived to be.

Figures shown in the table should not be taken at face value, as each is accompanied by a margin of error; such figures are just rough indications of change. An in fact, a different, less optimistic view is offered by a second 
international source of perceptions of corruption, namely Transparency International and its Corruption Perception Index (CPI).

The CPI (Table 2), although heavily criticized (Heywood 2016), provides a rough measure of the perceived extent of corruption in each country. Based on numerous opinion surveys, this index is sensitive to shifts in the patterns of criminal investigations for corruption and in the mass media's attention towards or away from corruption. When a prosecution against a well-known politician or businessman unfolds or when a newspaper starts a sort of media blitz against someone known to the public, surveys of corruption suddenly show a concomitant rise in perceptions of corruption.

Nevertheless, the CPI provides a very rough indication about where a certain country stands on the extent of perceived corruption relatively to other countries. Notably, the CPI is not based on uniform attitudinal surveys in all countries. Rather than being a reliable cross-national measure of corruption, the CPI is thus an indicator which is probably more useful to register trends over time in a country. In short, this indicator is useful, if one concentrates on long term trends and does not take year-by-year estimates at their face value.

Table 2. Extent of Perceived Corruption in the Western Balkans in the Comparative Perspective of Eastern Europe, According to Transparency International

\begin{tabular}{|l|c|c|c|}
\hline & $\mathbf{2 0 0 9}$ & $\mathbf{2 0 1 5}$ & change \\
\hline Albania & 32 & 36 & +4 \\
\hline Bosnia-Herzegovina & 30 & 38 & +8 \\
\hline Croatia & 41 & 51 & +10 \\
\hline FYR Macedonia & 38 & 42 & +4 \\
\hline Kosovo & 28 & 33 & +5 \\
\hline Montenegro & 39 & 44 & +5 \\
\hline Serbia & 35 & 40 & +5 \\
\hline Bulgaria & 38 & 46 & +8 \\
\hline Romania & 38 & 41 & +3 \\
\hline Centr East Europe average & 52.2 & 56 & +3.8 \\
\hline
\end{tabular}

Source: https://www.transparency.org/cpi2015/, last accessed on 21.06.2016. The Central Eastern European average is the average of scores of the Czech Republic, Hungary, Poland, Slovakia and Slovenia. The closer the score to 0 , the more corrupt a country is perceived to be.

As Table 2 indicates, first, there is an overall improvement as far as perceived corruption is concerned in the region, between 2009 and 2015; second, a similar, but not as extensive, improvement also characterizes 
Central Eastern European countries as well as Bulgaria and Romania; and, third, there are three sub-groups of West Balkan countries as far as perceived corruption is concerned. Kosovo, Bosnia-Herzegovina and Albania seem to be the most corrupt among West Balkan countries, while Croatia the least corrupt. The three cases under study in this chapter, namely, FYR Macedonia, Montenegro and Serbia, fall in between these two "extremes". Moreover, since the late zooos all three countries under study have made some progress towards becoming more transparent.

Overall, however, it seems that corruption is quite extensive in these three countries, as indicated by Tables 1 and 2 above. This claim is underscored by data of the Balkan Barometer, a cross-national public opinion survey covering the whole region (Table 3 ). This is a survey of people residing in the countries under study. The levels of perceived corruption and changes in perceived corruption in general over time, as reported in Transparency International' assessments, are too vague as indicators to understand political corruption on a country by country basis. The Balkan Barometer (Table 3) includes a more specific item on the corruption of government officials.

Table 3. Do you think that giving and taking of bribes, and the abuse of positions of power for personal gain, are widespread among the following? $(\%, 2015)$

$\begin{array}{lccc} & \text { National politicians } & \text { Local politicians } & \text { Judges } \\ \text { Kosovo } & 43 & 27 & 13 \\ \text { Bosnia-Herzegovina } & 38 & 23 & 11 \\ \text { Serbia } & 28 & 22 & 20 \\ \text { Croatia } & 46 & 38 & 14 \\ \text { Albania } & 37 & 18 & 47 \\ \text { FYR Macedonia } & 18 & 12 & 18 \\ \text { Montenegro } & 22 & 14 & 16\end{array}$

Source: Regional Cooperation Council (2015), Figure 74, p. 90.

As Table 3 shows, in 2015 public opinion in Western Balkans considered that national politicians, such as Ministers or MPs, constituted by far the most corrupt category among those usually suspected of engaging in corrupt acts. Other categories were people working in medical and health services. The latter services, in fact, came first in terms of perceptions about which institution is more corrupt in a similar survey in 2017 (Regional Cooperation Council 2017).

The practice of taking bribes and abusing positions of power is perceived to be more widespread among national and local politicians of Kosovo and Croatia than among the corresponding categories in FYR Macedonia, Montenegro and Serbia. This obviously does not mean that the politicians of the three countries under study are not corrupt but that they are perceived to be less corrupt. 
POLITIČKE PERSPEKTIVE

ČLANCI I STUDIJE

\section{FORMS, SCALE AND EXPLANATIONS OF CORRUPTION IN WESTERN BALKANS}

The different forms and scale of political corruption are obviously neither an exclusive problem of FYR Macedonia, Montenegro and Serbia nor more generally of Western Balkans. Corruption today surfaces in various advanced capitalist economies and consolidated democracies and it is quite widespread even in EU Member-States, such as Bulgaria, Greece, Italy and Romania. Across-the-board explanations of corruption in the modern world, such as, for example, the corruptive side of today's globalized capitalism, tell only part of the story. One needs to understand corruption in an appropriate context. In the three countries under study, corruption may be attributed to historical, geographical, and cultural reasons.

First, the Western Balkans, as other East European countries, to an extent still show traces of the historical legacy of communism. This is a legacy favoring the conflation rather than the careful and delicate distinction of political, administrative and economic spheres. As it is well known, state socialism used to put the law in the service of larger social transformation, such as the transition to communism. Former socialist regimes did not adhere to the rule of law and even impeded the development of civil society which could have limited the spread of corruption in the period of socialist rule and after its demise.

Secondly, the geographical position of the Western Balkans, in an area linking the East and the West, facilitates the emergence of corruption and organized crime. In the region of Western Balkans there are transit routes for illegal goods, human trafficking and the flow of unrecorded payments across newly demarcated or porous national borders.

Thirdly, another condition favoring corruption is the amalgam of ethnic and/or religious bonds tying members of small and larger West Balkan communities together. Such a community may form part of national majority in a West Balkan nation (e.g. Albanians in Kosovo), while it may be part of a minority in a neighboring state (e.g., Albanians in FYR Macedonia or Serbia). As it happens in other areas of the world, local norms may conflict with national norms. For example, norms of exchanging gifts and favors, to serve relatives, friends and other community members, may clash with norms related to modern state administration, such as rule of law, due diligence and transparency. Traditions of honorable behavior may be incompatible with meritocratic standards required by modern public bureaucracy and the level-playing field which is ideally required by the free market system. In other words, corruption is also facilitated by the type of social capital prevailing in the Western Balkans. Negative social capital, involving the strengthening of intra-communal ties at the expense of bridging any gaps with other communities and the nation as a whole, 
still prevails in the countries under study and the region as a whole (Sotiropoulos 2005).

And fourthly, while all three causes of corruption noted above are valid for the understanding of corruption in West Balkan countries and could be useful to explain corruption elsewhere in the world where similar historical and structural conditions apply, what is often forgotten is the role of human agency in affairs of corruption. A legacy of state socialist rule, ageold values and norms, and structures of untamed capitalism may provide the ideal environment for corruption to flourish, but it takes purposeful human action for corruption to occur. Corruption unfolds because individual actors, such as politicians, and collective agents, such as governing parties or well-oiled governing elites, consistently and in full conscience engage in corruption. In other words, as it will be argued below, what is specific about corruption in the countries under study is, first, the involvement of the peak of the government with corruption and, second, the systematic use of corruption as a weapon of the governing elites in political competition against the opposition.

\section{THE FAILURE OF ANTI-CORRUPTION IN WESTERN BALKANS}

In FYR Macedonia, Montenegro and Serbia, under pressure from international organizations such as the European Commission and the Council of Europe, anti-corruption has ostensibly become a major policy priority. New anti-corruption legislation has been passed and, in addition to the usual prosecutorial and judicial authorities, new anti-corruption institutions have been established by national governments. For example, Serbia has ratified all international anti-corruption conventions and has an AntiCorruption Agency, entrusted with the task to prevent corruption through collecting and analyzing data, and an Anti-Corruption Council which has a policy-advice role.

Montenegro has also ratified all relevant international legislation and in December 2014 passed comprehensive anti-corruption legislation. Based on this legislation, a new Anti-Corruption Agency was founded. However, the most important institution is the "Special Prosecutor's Office for the fight against corruption, organized crime, war crimes, terrorism and money laundering", established in February 2015 (Montenegro Ministry of Foreign Affairs and European Integration 2015). The Special Prosecutor acts before Montenegro's High Courts, directs the Police and is responsible for all pre-trial proceedings in the fields of competence mentioned in the institution's title.

FYR Macedonia has also been equipped with anti-corruption agencies, although the mobilization to fight corruption has been very uneven. Judi- 
POLITIČKE PERSPEKTIVE

ČLANCI I STUDIJE

cial authorities, such as the 15-member Judicial Council which was established in 2006, formally is independent in managing the justice system but in practice the independence of the Council's members is undermined by their lack of tenure. The European Commission reports that in 2007-2014 there were " 59 dismissal proceedings, resulting in 44 dismissals" (European Commission 2015a, 13). As for the country's prosecuting authorities, they suffer from the quasi-permanent lack of resources, such as their own budget, personnel and digital infrastructure.

Regarding specialized anti-corruption institutions in FYR Macedonia, such as the State Commission for the Prevention of Corruption (SPSC), a pattern of "selective passivity" is observed. According to the European Commission, "serious allegations against government officials have yet to trigger thorough investigations” (European Commission 2015a, 16).

The situation improved after the Przno agreement (see below) when a new agency, the Special Prosecution, assumed the task of examining evidence for corruption and other crimes which surfaced after wire-taped telephone conversations among government officials were leaked (Deutsche Welle 2016). By March 2016, i.e., six months after its establishment, the new prosecuting authority had started investigations in 30 cases of high-level crime and had probed 80 suspects (Marusic 2016).

In brief, in all three countries governments have been remarkably active in formulating a new anti-corruption framework. In practice, however, anticorruption has progressed with small steps. Except for, probably, Montenegro, anti-corruption has affected middle- and lower ranking officials. In other words, it is rare to see progress in fighting higher-level corruption.

In Montenegro, government-controlled anti-corruption authorities have turned against former members or past allies of the governing elite. In the so-called "Zavala and Kosljun" cases, two former Mayors and one Deputy Mayor of the city of Budva as well as a former parliamentarian of the ruling DPS party, charged with corruption, were convicted to prison sentences ranging from 3 to 6 years of imprisonment (European Commission 2015b, 54). Moreover, the Special Prosecutor's Office in Podgorica has prosecuted Duško Marković, who had been one of the three deputy prime ministers and top cadre of the ruling DPS party. Markovic was held in prison in 2016 and was to be tried for charges of corruption. However, as the European Commission states, "Montenegro's track record on effective investigation, prosecution and final convictions in corruption cases, particularly regarding high-level corruption, remains limited" (European Commission 2015b, 14).

Apprehending a few high-ranking politicians, accused of corruption, does not render Montenegro an ideal case of anti-corruption, but the corre- 
sponding record of the other two countries is even more disappointing. According to the European Commission, FYR Macedonia's track record is "weak on high-level political corruption. Serious allegations against senior government officials have yet to trigger thorough investigation. This selective passivity raises concerns over the independence of the police the Public Prosecutor's Office and the State Commission for the Prevention of Corruption (SPSC)" (European Commission 2015a, 15). Clearly, a large shadow was cast on the political will of the Gruevski government to fight corruption after the revelations about twenty thousand intercepted telephone communications and the leaking of the content of these communications in early 2016. Higher-standing government officials were implicated in corrupt practices in public procurement, urban planning, the financing of political parties and public employment.

The agreement signed in Przino, after the negotiations of 2 June-15 July 2015 between government and opposition, facilitated the establishment of a special prosecutor to investigate the extensive wiretappings. However, the appointed prosecutor, Katica Janeva, discovered that multiple impediments were placed in her way. For instance, in October 2015 Janeva's list of candidates for members of her prosecuting team was rejected by the Council of Public Prosecutors, only to be accepted with delay about a month later. After the strong challenge put to Gruevski by the opposition in the elections of December 2016 and the formation of a new coalition government between the Social Democratic party (SDSM) and Albanian parties in May 2017, Janeva was able to make visible progress in her investigations (which are still going on).

In Serbia, some progress has been made in fighting corruption. However, there is a low track record in investigating, indicting and convicting law violators, while anti-corruption agencies are neither properly overseen nor coordinated in the fight against corruption. Such problems remain because there is a lack of political will to fight corruption. In the words of the European Commission: “...strong political impetus has yet to be translated into sustained results” (European Commission 2015c, 13).

\section{POLITICAL CORRUPTION AS A STRATEGY TO GOVERN THE STATE AND SOCIETY}

In FYR Macedonia, as the wire-tapping affair has shown, the role of secret services in corruption cannot be underestimated. The secret services of that country have played a vital role in creating a corruption network with positive political benefits for the governing coalition, led by Gruevski.

The observed pattern of combining personal economic with political benefits is roughly the following: first, governing elites forge bonds with selected businessmen whom they favor, excluding their business compet- 
POLITIČKE PERSPEKTIVE

ČLANCI I STUDIJE

itors from public tenders or awards of public contracts; and, second, members of governing elites actively participate in business deals themselves. This creates an obvious conflict of interest, as elected officials only formally defend the public interest, but in practice use their position for personal benefit. The desired benefit is not necessarily economic, as in typical cases of corruption, but it is also political, defined in the narrow sense of prolonging one's stay in power by all possible, legal and illegal means, including corruption. In other words, in FYR Macedonia, as in the rest of countries under study, political corruption is not so much a means of personal enrichment as a vehicle for clinging to power. Thus, there are two obviously inter-connected functions of corruption, serving the interests of corrupt politicians, namely the political and the economic function.

One may understand the political and economic function of corrupt politics as an extension of Max Weber's conceptual distinction of living for politics and living off politics. As Weber stated in his "Politics as a Vocation":

"There are two ways of making politics one's vocation: Either one lives 'for' politics or one lives 'off' politics. By no means is this contrast an exclusive one. The rule is, rather, that man does both, at least in thought, and certainly he also does both in practice. He who lives 'for' politics makes politics his life, in an internal sense. Either he enjoys the naked possession of the power he exerts, or he nourishes his inner balance and self-feeling by the consciousness that his life has meaning in the service of a 'cause.' In this internal sense, every sincere man who lives for a cause also lives off this cause. The distinction hence refers to a much more substantial aspect of the matter, namely, to the economic. He who strives to make politics a permanent source of income lives 'off' politics as a vocation, whereas he who does not do this lives 'for' politics." (Weber 1919, 5).

Max Weber's conceptual dichotomy can be used to understand how corrupt politicians in practice do both, namely live for politics and off politics. In a way that Max Weber would certainly disapprove, corrupt politicians use corruption to continue living for politics, namely to fulfill their passion for politics and hold on to power. At the same time, as Weber admits in the above passage, the same politicians strive to "to make politics a permanent source of income". Obviously, they do so in a completely unbounded way, since they do not limit themselves to living off their salary as prime minister or minister, but use their position of authority as a resource or spring board to become wealthy. 


\section{THE POLITICAL FUNCTION OF CORRUPTION: CORRUPT PRACTICES AS MEANS TO CONSOLIDATE POLITICAL POWER}

Using corruption as a means of prolonging one's stay in power can be done in more than one ways. Government officials award contracts of public works to domestic and foreign businessmen in a very selective manner, as public tenders are not managed in a transparent way.

For example, in FYR Macedonia, some businessmen were already prominent before VMRO-DPMNE's rise to power in 2006 and forged an alliance with the government. An example is the 8o-year old Ljubisav IvanovDzingo, leader of the small, pro-government Socialist Party of Macedonia (SPM) and for the last forty years general manager of a Kratovo-based mining plant "Sileks" (Sobranie 2017). He forged close relations with the party of Gruevski and became his ally. Some other businessmen were selected "from above" to implement state plans, such as road construction. Other ones were not visible or had a small niche in the market, before Gruevski's party won elections. After wining government power, the new rulers molded them as business partners.

Moreover, in FYR Macedonia other businessmen were not citizens of the country but convenient foreign business partners, such as Greece's Dimitris Kontominas. The latter had ties not only with the VMRO-DPMNE in 2006-2016, but also with the preceding SDSM government which was in power until 2006. Significantly, according to Transparency International, in the context of the project "Skopje 2014" Kontominas bought land in the center of Skopje with the aim to construct two buildings, following the neo-baroque style favoured by the Gruevski government. He was also active in telecommunication enterprises doing business with the government of FYR Macedonia (Popovic 2012). According to a testimony given in late 2014 to a US court by Slobodan Bogoevski, former Deputy Secretary for State Security in FYR Macedonia, by 2006 Kontominas had already been involved in the bribing of social democratic (SDSM) politicians, in exchange for barring the access of his competitors to the mobile phone market in the country. For this case there were never any charges against Macedonian politicians. There were charges against foreign citizens, but the case was dropped in 2008 (Marusic 2015).

In exchange for such government-led favors to their businesses, businessmen who have emerged and flourished through the government's preferential treatment, finance the governing coalition parties and - if they are also active in the media sector - diffuse government propaganda to the people.

In this sense, the government intervenes in the economy not so much to curb the inequalities created by the functioning of the capitalist market, 
but to construct a previously non-existing or dormant, governmentfriendly business elite. The active role of the governing coalition in creating a government-business nexus includes an even more debatable part. This is the systematic marginalization or even expulsion from the market of those businessmen who are reluctant to cooperate with the government or openly oppose it. The example of the TV station A1 in FYR Macedonia is telling. The station's owner, Velija Ramkovski, and journalists had criticized the VMR-DPMNE. Then, the financial police (tax revenue officers) raided the station in November 2010 (Marusic 2015 and 2016). In July 2011 the station declared bankruptcy and its owner was escorted to prison. Essentially this station, which had been broadcasting since 1993, was silenced after the government decided that it could not fully control it.

If the case of A1 TV shows how unwanted businessmen are excluded from the market, how is the government-business nexus created in the first place? Basically, in each major sector of the market the government favors one or more companies and makes them dependent on state funds in at least two different ways. First, dependency is created through distributing state funds to more than one business competitors at a time or in sequence. Second, dependency is reproduced through purposeful delays in paying arrears to private suppliers of goods and services to the state. Such tactics makes business companies wait for the whimsical decisions of power-holders to open the state coffers. In other words, more than one companies benefit from government outlays at unpredictable intervals, while no company is allowed to become too large as to free itself of government control.

It would be wrong to assume that in FYR Macedonia all private companies are mere puppets of the government and have no room for manoeuver. Depending on the business sector in question, there are companies of local businessmen as well as local affiliates of multi-national companies which closely monitor shifts in the political scene of FYR Macedonia. From time to time they attempt to stay neutral towards large parties or abandon their alliance with a declining political party and take sides with a rising party.

Shorn to its essentials what all this amounts to is that in FYR Macedonia it is the government who captures businesses than the reverse. The government influences businessmen, not vice versa, unless of course we include in this equation the influence of large foreign companies who have invested funds in the country. The balance of power between the government and foreign investors is delicate, even though the government is investment-friendly and would normally not alienate foreign investors.

For example, the Austrian utility company EVN acquired 90 per cent of the Macedonian state electricity distribution company in FYR Macedonia in 2006. The Austrian company has operated under the name EVN 
since 2008 and has obtained policy leverage in the energy sector. Thus, the Austrian company has become a privatized distributor which dominated the electricity distribution sector in FYR Macedonia, but had to face government-driven sudden cuts of the tariffs it charged customers and increases in the prices it paid to the state-owned electricity generator (Kester 2013).

In Montenegro, the political functions of corruption were manifested in the drive of the PM Milo Đukanovic himself, who, besides leading the governing Democratic Party of Socialists (DPS), has companies of his own. For instance, he is active in the banking sector and the tourism sector (Patrucic, Brkic and Celic 2009, Perovic-Korac and Tadic-Mijoivic 2011). He owns Prva Banka and through his relatives he has invested in tourism on the Montegrin coast. He has also allowed the creation of foreign monopolies in other sectors such as oil industry (distribution network) and tourism. Major foreign companies are the Swiss - Egyptian company ORASCOM which has invested in Lustica Bay, the Azeri state-owned oil company SOCAR, which has invested in banking and high-end tourism, and the Greek company EKO which prevails in the oil and gasoline distribution network. (Garaca 2015). Essentially, though deals with domestic and foreign businessmen the PM and his family for the last 25 years control Montenegro's economy, thus creating support for the continuous return of the DPS to power through elections.

\section{CONCLUSIONS: \\ POLITICAL CORRUPTION AS A STRATEGY TO GOVERN SOCIETY AND CONSOLIDATE POLITICAL POWER}

The Western Balkans is a region fraught with political corruption, but the benefits which political officials reap from corruption are not limited to personal enrichment. They extend to their consolidating political power. Our purpose has been to analyze corruption not as a temporary pathological symptom or a side-effect of a dys-functioning democratic regime, but as a more systematic strategy to govern society by political elites which on purpose use corruption to win elections and prolong their stay in power.

Once in power, political elites create a power base among businessmen who are involved in networks of corruption with government ministers and heads of state agencies, if not the head of the government himself or herself. Either the government hand picks previously unknown businessmen on whom it passes state assets, on funds raised by governmentcontrolled banks; or it builds linkages with established businessmen in exchange for services the latter would provide to the government. Such services would include influencing employees working for the pro-government businessman; selectively hiring the most pro-government among job 
candidates; contributing to government-sponsored local development or social protection projects; and openly or discreetly financing the electoral campaign of the governing party.

The most useful part to be played by pro-government business elites involves their control of private mass media, such as newspapers and TV stations. Ostensibly out of the reach of government and managed in a manner formally autonomous and different from the governmentcontrolled state media, such private pro-government media can serve both the task of diffusing to the electorate the government line on disputed issues and discrediting the opposition, through hostile reportages or even smearing campaigns against the government's opponents in the party system or civil society.

The power base woven through such a government - business nexus of relations is extended to the middle and lower ranks of public administration and local government, including street-level bureaucracy. Thus middle- and low-income groups, whose primary source of income is a public sector salary, can look forward to additional income. This is income either directly obtained through bribe-taking in the public employees' encounters with citizens or income trickling down to the middle and lower ranks of public bureaucracy from the higher echelons of government. At these echelons large sums of money are illegally handed out to government officials in exchange for passing tailor-made legislation which suits the interests of selected businessmen or issuing administrative acts convenient to the same people.

Nothing of this sort can be smoothly carried out without the involvement of public employees at different levels of the administrative hierarchy, a fact which explains the need to win over such employees, to involve them in less than transparent citizen-administration relations and to keep doing so, at least until the next elections. The integration of public employees into networks of corruption provides a base of political support for corrupt governing elites.

To sum up, networks of business interests act in conjunction with corruption-happy governing elites. This is not a usual case of policy capture observed in typically corrupt states (Hellman, Jones and Kaufmann 200o), but rather a two-way arrangement. It is an arrangement convenient to businessmen and obviously to politicians who often swap that identity of politician for the identity of businessman. Governing elites carve out state resources and formulate policies to accommodate interests of specific businesses and insiders. Conversely, business interests liaise with governing elites to capture profitable policy sectors.

Moreover, governing elites use the tool of anti-corruption not so much to control corruption in their country but in a perverse manner. Anti- 
corruption becomes a tool to legitimize government and delegitimize opposition as well as to confront disloyal party cadres and uncooperative businessmen and mass media (e.g., the cases of Marović in Montenegro and Mišković in Serbia; see Pantovic 2016).

In short, corruption in the three cases under study shows that in addition to obtain personal benefit, corrupt practices can be used as a strategy to consolidate political power. Corruption is the use of public office for private benefit and for prolonging one's term in power though creating strongholds among business elites and among public officials at various ranks who are involved in webs of corruption. In the three countries under study, anti-corruption legislation remains under-developed, mechanisms of controlling corruption are only skeletal and there are a few, if any, checks and balances against the executive. All these are not symptoms of technical inefficiency or inadequate resources dedicated to controlling corruption. They are the result of the strategy of governing elites to retain power. In brief, high-level or grand political corruption in FYR Macedonia, Montenegro and Serbia is something larger than a side-benefit of exercising government authority. Such corruption is one of the several means which an elite purposefully uses to stay in power, once it has arrived in power, by winning national elections.

Under such constraints put to democratic institutions by elites which have been elected to power democratically, democracy suffers from complicated distortions. Political parties compete for state sources which, after winning elections, they put to corrupt uses. Through enlarging opportunities for corruption, governing parties and party leaders create business ties and bases of political support, while, if challenged by the opposition, they use mechanisms of anti-corruption to discredit their political opponents. Thus, corruption and anti-corruption evolve together, negatively affecting democracy in obvious and also less than expected way

\section{REFERENCES}

Bartlett, William. 2007. "Western Balkans.” In ed. David Lane and Martin Myant, Varieties of Capitalism in the Post-Communist Countries, London: Palgrave, pp.201-220.

Bieber, Florian. 2015. "Gruevski Does not Deserve Any More Chances." 23 June 2015, available at http://www.balkaninsight.com/en/blog/gruevski-does-notdeserve-any-more-chances, last accessed on 22,12.2017.

Deutsche Welle. 2016. “ Special Prosecution: New Faces, New Hope in Macedonia”, 23 May 2016, available at http://www.dw.com/en/special-prosecution-new-faces-new-hope-in-macedonia/a-19277508, last accessed on 20.12.2017. 


\section{4 \\ POLITIČKE PERSPEKTIVE \\ ČLANCI I STUDIJE}

European Commission. 2015a. “The Former Yugoslav Republic of Macedonia Report 2015”, available at http://ec.europa.eu/enlargement/pdf/key_documents/2015/20151110_report_the_former_yugoslav_republic_of_macedonia. pdf, last accessed on 22.12.2017.

European Commission. 2015b. "The Republic of Montenegro Report 2015”, available at https://ec.europa.eu/neighbourhood-enlargement/sites/near/files/ pdf/key_documents/2015/20151110_report_montenegro.pdf, last accessed on 22.12.2017.

European Commission. 2015c. “The Republic of Serbia Report 2015”. https:// ec.europa.eu/neighbourhood-enlargement/sites/near/files/pdf/key_documents/2015/20151110_report_serbia.pdf, last accessed on 22.12.2017.

European Parliament. 2015. "Corruption - Still a Major Problem in Several Western Balkan countries”, European Parliament Briefing, drafted by Velina Lilyanova, Strasbourg, May 2015.

Garaca, Maja. 2015. “Montenegro's Uniprom Plans New Aluminum Smelting Unit by November 2016." SEENEWS, Podgorica, 29 September 2016, available at https://seenews.com/news/montenegros-uniprom-plans-new-aluminium-smelting-unit-by-nov-2016-report-495050, last accessed on 20.06.2016.

GRECO. 2013. "Fourth Evaluation Round - Evaluation Report 'The Former Yugoslav Republic of Macedonia”. Strasbourg, December 2013.

GRECO. 2015a. "Fourth Evaluation Round - Evaluation Report Serbia”. Strasbourg, June 2015.

GRECO. 2015b. “Fourth Evaluation Round - Evaluation Report Montenegro". Strasbourg, June 2015.

Hellman, Joel S., Geraint Jones and Daniel Kaufmann. 20oo. "Seize the State, Seize the Day State Capture, Corruption and Interest in Transition.” September, Washington DC: The World Bank.

Heywood, Paul. 2016. "The Corruption Perceptions Index (CPI): The Good, the Bad and the Ugly." Blog of the British Academy, available at https://www.britac. ac.uk/blog/corruption-perceptions-index-cpi-good-bad-and-ugly, last accessed on 22.12.2017.

Kester, Eddy . 2013. "Macedonia: Long-terms on energy prove difficult", Financial Times, 12 September 2013.

Marusic, Sinisa Jakov. 2015. "Macedonian Politicians Deny Telecom Bribe Claims", Balkan Insight, 9 September 2015, http://www.balkaninsight.com/en/article/ macedonian-politicians-deny-telecom-scam-claims-09-07-2015, last accessed on 19.12.2017.

Marusic, Sinisa Jakov. 2016. “Macedonia ‘Special Prosecution' Seriously Probing Top Officials", Balkan Insight, 26 March 2016, available at http://www.balkaninsight.com/en/article/macedonia-special-prosecution-on-right-track--03-182016, last accessed on 19.12.2017. 
Montenegro Ministry of Foreign Affairs and European Integration. 2015. "Exchange of Information on the OSCE Code of Conduct on Politico-Military Aspects of Security", Vienna, 5 June 2015, available at http://www.osce.org/fsc/ 162506?download=true, last accessed on 22.12.2017.

Pantovic, Milivoje. 2016. "Serbia Court Jails Miskovic for Five Years.” 20 June 2016, available at http://www.balkaninsight.com/en/article/serbian-tycoon-sentenced-five-years-in-prison-o6-20-2016, last accessed on 19.12.2017.

Patrucic, Miranda, Mirsad Brkic, and Svjetlana Celic. 2009. "Djukanovic's Montenegro: A Family Business.” 2 June 2009, available at https://www.icij.org/ project/tobacco-underground/djukanovics-montenegro-family-business, last accessed on 21.12.2017.

Perovic-Korac, Milena and Milka Tadic-Mijoivic. 2011. "Djukanovic's Clan Property”. Monitor Online, 11 March 2011, available at http://www.monitor.co.me/ index.php?option=com_content $\&$ view=article\&id=2415:djukanovics-clanproperty\&Itemid=2914, last accessed on 22.12.2017.

Popovic, Mirkica. 2012. "Who is Kontominas". 2 February 2012, available at, http:// www.transparency.mk/en/index.php?option=com_content\&task=view\&id=4 58, last accessed on 22.12.2017.

Regional Cooperation Council. 2015. "Balkan Barometer 2015, Cross-national Public Opinion Survey of West Balkan populations.” Available at http://www.rcc. int/seeds/files/RCC_BalkanBarometer2015_PublicOpinion_FIN_forWeb.pdf, last accessed on 21.12.2017.

Regional Cooperation Council .2017. "Balkan Barometer 2017, Cross-national Public Opinion Survey of West Balkan populations.” Available at http://www.rcc. int/seeds/files/RCC_BalkanBarometer_PublicOpinion_2017.pdf, last accessed on 22.12.2017.

Sobranie. 2017. Assembly of the Republic of Macedonia's official website, http:// www.sobranie.mk/default.asp?ItemID=6FoB81F7BAoA664BB56D69BA9ACA CFB8, last accessed on 22.12.2017.

Sotiropoulos, Dimitri A. 2005. "Positive and Negative Social Capital and the Uneven Development of Civil Society in Southeastern Europe", South East European and Black Sea Studies, 5 (2): 243-256.

Tomovic, Dusica. 2016. “Montenegro’s Ex-President Marovic Faces Jail for Corruption." 17 May 2016, available at http://www.balkaninsight.com/en/article/montenegro-jails-ex-president-marovic-for-corruption-05-17-2016, last accessed on 21.12.2017.

Van Ham, Peter. 2014. "Gridlock, Corruption, and Crime in the Western Balkans: Why the EU Must Acknowledge its Limits." Clingendael Report, The Netherlands Institute of International Relations, October 2014, available at http:// www.clingendael.nl/sites/default/files/Gridlock\%2oCorruption\%2oand\%20Cr ime\%2oin\%2othe\%2oWestern\%2oBalkans.pdf, last accessed on 11.05.2016. 
Weber, Max. 1919. "Politics as a Vocation”, Munich, 28 January 1919, available in English translation at http://anthropos-lab.net/wp/wp-content/uploads/2011/12/ Weber-Politics-as-a-Vocation.pdf, p. 5, last accessed on 20.12.2017.

World Bank. 2015. Worldwide Governance Indicators, available at http://info.worldbank.org/governance/wgi/index.aspx\#doc, last accessed on 21.06.2016.

Zaev, Zoran. 2015. Press conference. 15 March 2015, available at http://arhiva.sdsm. org.mk/print.aspx?articleId=11853, last accessed on 22.12.2017

\section{SAŽETAK}

\section{KORUPCIJA, ANTIKORUPCIJA I DEMOKRACIJA NA ZAPADNOM BALKANU}

U članku se razmatraju korupcija, antikorupcija i demokracija na Zapadnom Balkanu s naglaskom na Makedoniju, Crnu Goru i manjim dijelom na Srbiju. Zaključci članka ne vrijede nužno za sve demokracije Zapadnog Balkana. Glavna istraživačka pitanja su slijedeća: koje su političke funkcije korupcije (pored ekonomskih dobitaka) i kako korupcija služi za reproduciranje istih elita na vlasti. Istraživanje prikazano u članku pokazuje da je korupcija na najvišim razinama vlasti u Makedoniji, Crnoj Gori i Srbiji ipak nešto više nego popratna ekonomska dobit od vršenja vlasti. Takva je korupcija sredstvo koje elite koriste kako bi zadržale vlast koju su izvorno dobile na demokratskim izborima. Nadalje, antikorupcijski mehanizmi se zapravo često koriste kako bi se diskreditirali politički protivnici u opoziciji. Demokracija na Zapadnom Balkanu je tako iskrivljena na očite, ali i na manje očite načine.

KLJUČNE RIJEČI: Zapadni Balkan, korupcija, antikorupcija, Makedonija, Crna Gora, Srbija 